\title{
Pasvirusio plokščio paviršiaus aušinimas dvifazių putų srautu
}

\author{
Martynas Gylys \\ Kauno technologijos universitetas, \\ Energetikos technologiju institutas, \\ K. Donelaičio g. 20-104 LK, \\ LT-44239 Kaunas \\ El.paštas: martynas.gylys@ktu.lt
}

\begin{abstract}
Eksperimentiškai ir analitiškai tirti šilumos mainai tarp pasvirusio plokščio ịkaitusio paviršiaus ir jị išilgai aptekančio kylančio statiškai stabilių putų srauto. Nustatyta, kad ant pasvirusio plokščio paviršiaus susiformuoja iš putų nusidrenavusio skysčio sluoksnis. Paviršiaus aušinimo intensyvumą lemia nusidrenavusio (drenažinio) tirpalo sluoksnio storis, tirpalo greitis ir temperatūra. Šie parametrai priklauso nuo kanalu tekančių putų debito, temperatūros ir dujingumo. Sudarytos analitinės lygtys įvertinti drenažinio tirpalo sluoksnio storị, debitą, vidutinị tirpalo greitị bei temperatūrą. Nustatyta, kad, skirtingai nei vertikalų plokščią paviršių aušinant putomis, vidutinis pasvirusio plokščio paviršiaus aušinimo intensyvumas didejja (didejjant putų srauto greičiui), pasiekia maksimumą ir pradeda mažèti. Eksperimentinių tyrimų rezultatai palyginti su analitinių tyrimų rezultatais.
\end{abstract}

Raktažodžiai: dvifazių putų srautas, pasviręs plokščias paviršius, drenažinio tirpalo sluoksnis, šilumos mainai

\section{IVADAS}

Šiuo metu pramonèje plačiai paplitusiuose rekuperaciniuose šilumokaičiuose šilumos mainų intensyvumas priklauso nuo trijų pagrindinių veiksnių: šilumos mainų paviršiaus ploto, šilumnešių temperatūrų skirtumo ir šilumos perdavimo koeficiento dydžio $[1,2]$. Šilumos mainų paviršiaus ploto didinimas susijęs su didesnèmis medžiagų sąnaudomis, didesniais šilumokaičių matmenimis, sudètingesne šilumokaičių konstrukcija. Padidinti šilumnešių temperatūrų skirtumą ne visada leidžia techninès galimybès, iš kitos pusès - tai nenaudinga ir ekonomiškai (sudeginama daugiau kuro ir t. t.). Lieka trečiasis būdas, leidžiantis padidinti perduodamos šilumos kiekị - tai paties šilumos mainų proceso vyksmo intensyvinimas, veikiantis šilumos perdavimo koeficiento padidejimą. Šilumos perdavimo nuo vieno šilumnešio kitam proceso intensyvumą paprastai lemia ne tik šilumnešius skiriančio paviršiaus (sienelès) šilumos laidumas, bet ir šilumos atidavimo nuo paviršiaus šilumnešiui (arba nuo šilumnešio paviršiui) intensyvumas, t. y. šilumos atidavimo koeficiento dydis. Šilumos atidavimo koeficientą galima didinti įvairiais būdais: turbulizuojant paviršių aptekančio šilumnešio srautą, vietoje dujinio šilumnešio naudojant skystajị šilumnešį arba šilumnešį, kuris keičia agregatinę būseną (verdantị, besikondensuojantị) ir t. t. Pastaruoju metu nemažas dèmesys skiriamas dvifaziams (dažniausiai dujų ir skysčio) šilumnešiams intensyvinant šilumos atidavimo procesą [3-5]. Šiam tikslui tinka ir tokia dvifazè sistema, kaip statiškai stabilios putos [6], pasižyminčios daugeliu privalumų, kurių svarbiausias yra tas, kad jau esant nedideliems putų srauto greičiams $(0,1-0,5 \mathrm{~m} / \mathrm{s})$ bei mažiems masiniams debitams (nedaug besiskiriantiems nuo dujinio šilumnešio), pasiekiamas sąlyginai didelis šilumos atidavimo intensyvumas. 
Kauno technologijos universiteto Šilumos ir atomo energetikos katedroje bei Energetikos technologijų institute daug metų tiriamas šilumos atidavimas statiškai stabilių putų srautui. Vertikaliu putų srautu aptekamo pavienio vamzdžio [6], vamzdžių eilès [6], šachmatinio [7, 8], koridorinio $[9,10]$ ir nestandartinio $[11,12]$ vamzdžiu pluoštų, vertikalaus plokščio paviršiaus [13] šilumos atidavimo tyrimai atskleidè statiškai stabilių putų taikymo šilumokaičiuose privalumus ir trūkumus.

Iki šiol tirtas šilumos atidavimas nuo ịkaitusio paviršiaus (cilindrinio arba plokščio) vertikalia kryptimi (aukštyn arba žemyn) tekančiam putų srautui. Tačiau praktikoje šilumnešių aptekamieji paviršiai gali būti ne tik vertikalūs, bet ir pasvirę bet kokiu kampu nuo vertikalès [2]. Vienfazio šilumnešio (skysčio arba dujų) arba dvifazio (dažniausiai vandens ir vandens garų arba oro ir skysčio lašelių) šilumos mainų intensyvumo kitimas pasvirusiame kanale yra tirtas gana plačiai [14]. Pasvirusio plokščio paviršiaus šilumos atidavimas putų srautui, kaip rodo skelbiamų darbų analizè, nėra tirtas. Tirpalo drenažas iš putų, ant ịkaitusių paviršiu ir kanalo sienelių formuojantis priešingą (arba tą patị) putu srautui tekančio tirpalo sluoksni (plèvelę) bei perskirstantis tikrojo tūrinio putų dujingumo pasiskirstymą ne tiktai išilgai, bet ir skersai putų srauto, įneša daug savitumų ir komplikuoja šilumos atidavimo proceso tyrimą.

Šiame straipsnyje analizuojamas pasvirusio plokščio paviršiaus aušinimas statiškai stabilių putų srautu, pateikiami analitinių ir eksperimentinių tyrimų rezultatai.

\section{TEORINIAI TYRIMAI}

\section{Hidrodinamika}

Pasvirusiame kanale lemiamą reikšmę pasvirusio plokščio paviršiaus šilumos atidavimo putų srauto intensyvumui turi drenažiniai procesai $[6,15]$, dèl kurių aušinamas paviršius padengiamas nusidrenavusio tirpalo sluoksniu. Tirpalo sluoksnio hidrodinaminių charakteristikų (sluoksnio storio, tekèjimo krypties, greičio ir kt.) radimas būtinas tiriant tokio paviršiaus šilumos atidavimą putų srautui.

Pasvirusiu kanalu aukštyn tekančios putos eksperimentiniame ruože sausèja, didëja jų dujingumas, nes dalis tirpalo iš putų Gibso kanalais ir gretimus burbulus skiriančiomis sienelèmis drenuojasi $[15,16]$. Ant apatinès kanalo sienelès formuojasi priešinga arba ta pačia putu srautui kryptimi tekančio tirpalo sluoksnis. Tirpalo drenažas iš putu vyksta veikiant gravitacinèms, kapiliarinèms, molekulinèms ir elektrostatinèms jègoms. Kapiliarinès, molekulinès ir elektrostatinès jègos vyrauja tada, kai putų dujingumas yra artimas vienetui (prieš pat putų sinerezę - suirimą). Kai putos yra pakankamai drègnos $\left(1 \mathrm{~m}^{3}\right.$ putu yra daugiau kaip $1 \mathrm{~kg}$ tirpalo), drenažo proceso eigą lemia gravitacinès jègos $[15,17]$. Kadangi eksperimentiškai tirtuose šilumos mainu procesuose naudotu statiškai stabilių putų tūrinis debitinis dujingumas mažesnis kaip 0,999 , tai skaičiuojant nusidrenavusio tirpalo hidrodinaminius parametrus ivertinta tik gravitacinių jègų itaka $[6,15]$.

Putų kanalas (1 pav.) vertikaliais pjūviais padalinamas i atskiras elementarias zonas: 1, 2, 3.......(n-1), n. Kai tiriamo-
1 pav. Putu tirpalo drenažas pasvirusiame kanale. 1 - tirpalo sluoksnis; 2 - putu srautas; 3 - eksperimentinis ruožas

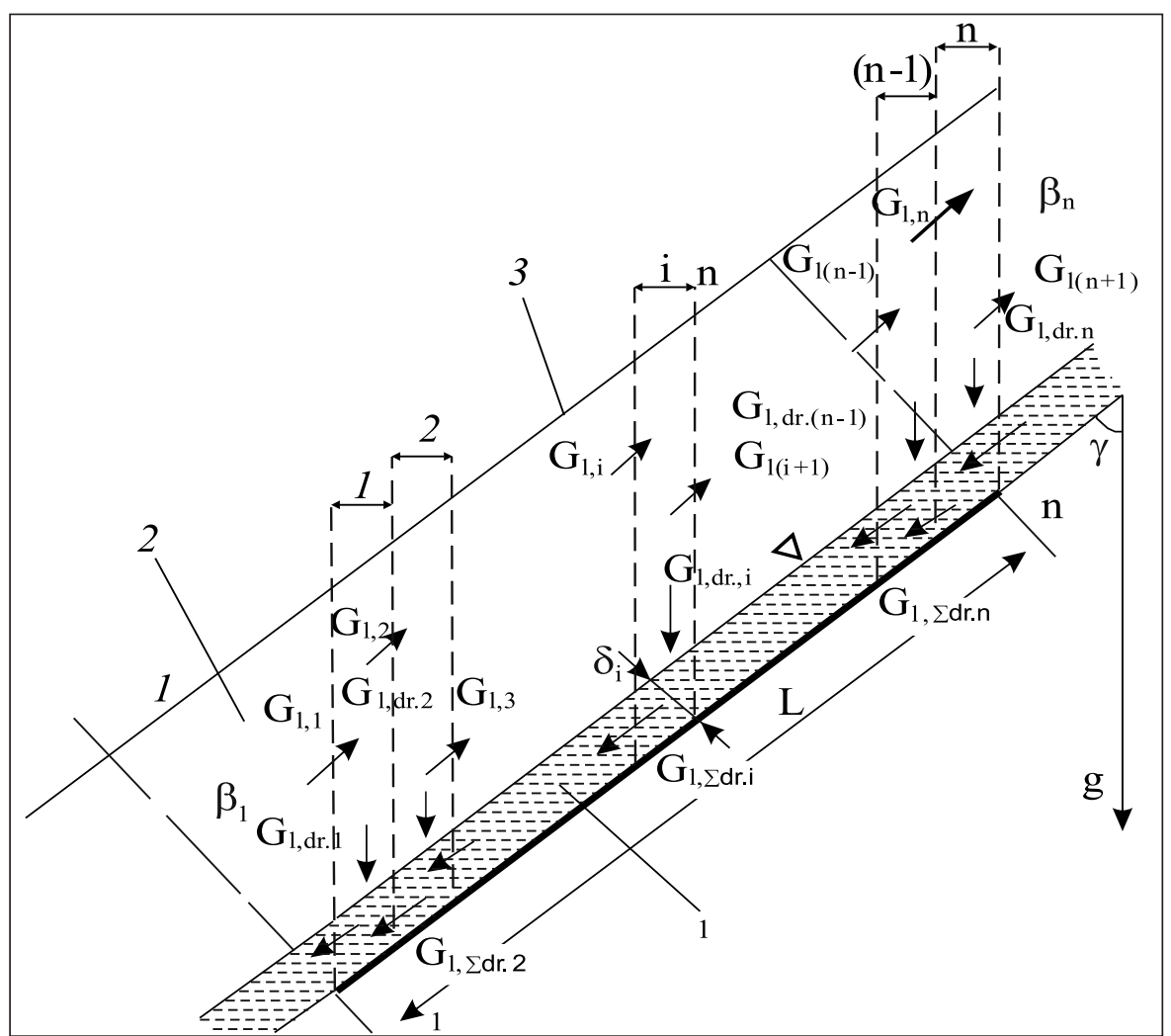


jo eksperimentinio ruožo ilgis $L(\mathrm{~m})$, o elementarios zonos ilgis $l_{i}(\mathrm{~m})$, tai elementarių zonų skaičius $n=L / l_{i}$. Straipsnyje pateiktuose grafikuose $x_{i}=l_{i} \cdot i$ arba $x_{i}=L \cdot(i / n)$.

Priimama, kad putų srauto dujingumas nekinta elementarios zonos ribose, o keičiasi šuoliškai pereinant iš vienos zonos ị kitą. Be to, priimama, kad kiekvienoje zonoje nusidrenuoja $n$-oji dalis tirpalo, su putomis atnešamo it tą zoną.

Tokiu atveju gaunama:

lygtis, igalinanti apskaičiuoti ị bet kurią elementarią zoną su putomis atnešamo tirpalo debitą, $\mathrm{kg} / \mathrm{s}$ :

$$
G_{l, i}=G_{l, 1}\left(\frac{n-1}{n}\right)^{(i-1)}
$$

čia: $i$ - zonos numeris $(i \leq n) ; n$ - zonų skaičius, $G_{l, 1}-\dot{i}$ pirmąją zoną su putomis atnešamo tirpalo debitas, $\mathrm{kg} / \mathrm{s}$;

lygtis, skirta įvertinti kiekvienoje zonoje iš putų nusidrenuojančio tirpalo srautą, $\mathrm{kg} / \mathrm{s}$ :

$$
G_{l, d r . i}=\frac{G_{l, 1}}{n}\left(\frac{n-1}{n}\right)^{(i-1)}
$$

lygtis, kuria galima surasti bet kurioje zonoje tekančio nudrenuoto tirpalo debitą, $\mathrm{kg} / \mathrm{s}$ :

$$
\Delta G_{l, i}=G_{l, \Sigma d r . i}=G_{l, 1}\left[\left(\frac{n-1}{n}\right)^{(i-1)}-\left(\frac{n-1}{n}\right)^{(n)}\right] .
$$

Nustatant su putomis pernešamo tirpalo debitą (1 lygtis), būtina žinoti ì pirmąą (apatinę) zoną su putomis įnešamo tirpalo debitą $G_{l, 1} \mathrm{~kg} / \mathrm{s}$ :

$$
G_{l, 1}=G_{l, n} \cdot \frac{1}{\left(\frac{n-1}{n}\right)^{(n-1)}}
$$

bei su putomis pernešamo tirpalo debitą paskutineje (n-ojoje) zonoje $G_{l, n}, \mathrm{~kg} / \mathrm{s}$ :

$$
G_{l, n}=\left(\frac{1-\beta_{n}}{\beta_{n}}\right) \cdot G_{g} \cdot \frac{\rho_{l}}{\rho_{g}},
$$

čia: $G_{g}$ - masinis ị putų aparatą tiekiamų dujų (oro) debitas, $\mathrm{kg} / \mathrm{s} ; \rho_{l}, \rho_{g}$ - tirpalo ir dujų tankis, $\mathrm{kg} / \mathrm{m}^{3} ; \beta_{n}$ - vidutinis masinis debitinis putų dujingumas ištekant iš eksperimentinio ruožo, randamas eksperimentiškai pagal tiekiamo ị aparatą tirpalo ir dujų masinius debitus:

$$
\beta_{n}=\left(1+\frac{G_{l, n}}{G_{g}} \cdot \frac{\rho_{g}}{\rho_{l}}\right)^{-1} .
$$

Priimama, kad su putomis iš eksperimentinio ruožo išnešamo tirpalo debitas $G_{l, n}$ yra lygus ị putų generavimo kanalą tiekiamo naujo tirpalo debitui $G_{l}, \mathrm{~kg} / \mathrm{s}$ :

$$
G_{l, 1}=G_{l, n} \cdot \frac{1}{\left(\frac{n-1}{n}\right)^{(n-1)}} .
$$

Geometrinè (3) lygties interpretacija pavaizduota 2 pav.

Žinant kiekvienoje elementariojoje zonoje su putomis pernešamo tirpalo debitą $G_{l, i}$ ir tariant, kad masinis dujų (oro) debitas (kg/s) nekinta eksperimentinio ruožo ilgyje $\left(G_{g}=G_{g, i}=\right.$ const), galima surasti vidutinị masinị debitinị putų dujingumą kiekvienoje zonoje (8 lygtis, 3 pav.):

$$
\beta_{i}=\left(1+\frac{G_{l, i}}{G_{g}} \cdot \frac{\rho_{g}}{\rho_{l}}\right)^{-1} .
$$

Ant kaitinimo paviršiaus (apatinė kanalo plokštuma) tekančio drenažinio tirpalo sluoksnio hidrodinamika turi lemiamos itakos šilumos atidavimui nuo paviršiaus putu srautui, todèl būtina surasti skysčio greičio pasiskirstymą drenažinio tirpalo sluoksnio skerspjūvyje (4 pav.).

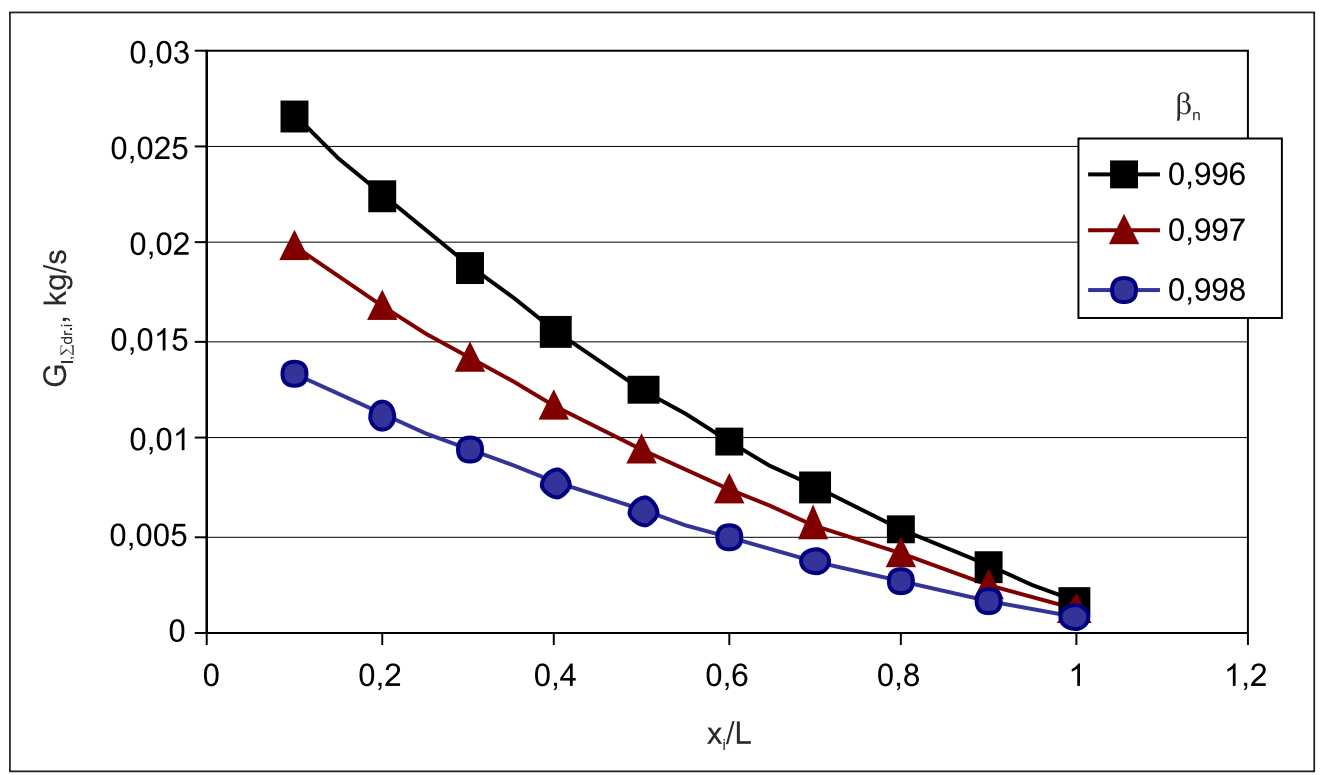

2 pav. Drenažinio tirpalo debito sluoksnyje kitimas išilgai kanalo $\left(\bar{w}_{g}=0,2 \mathrm{~m} / \mathrm{s} ; \mathrm{L}=0,5 \mathrm{~m}\right)$ 


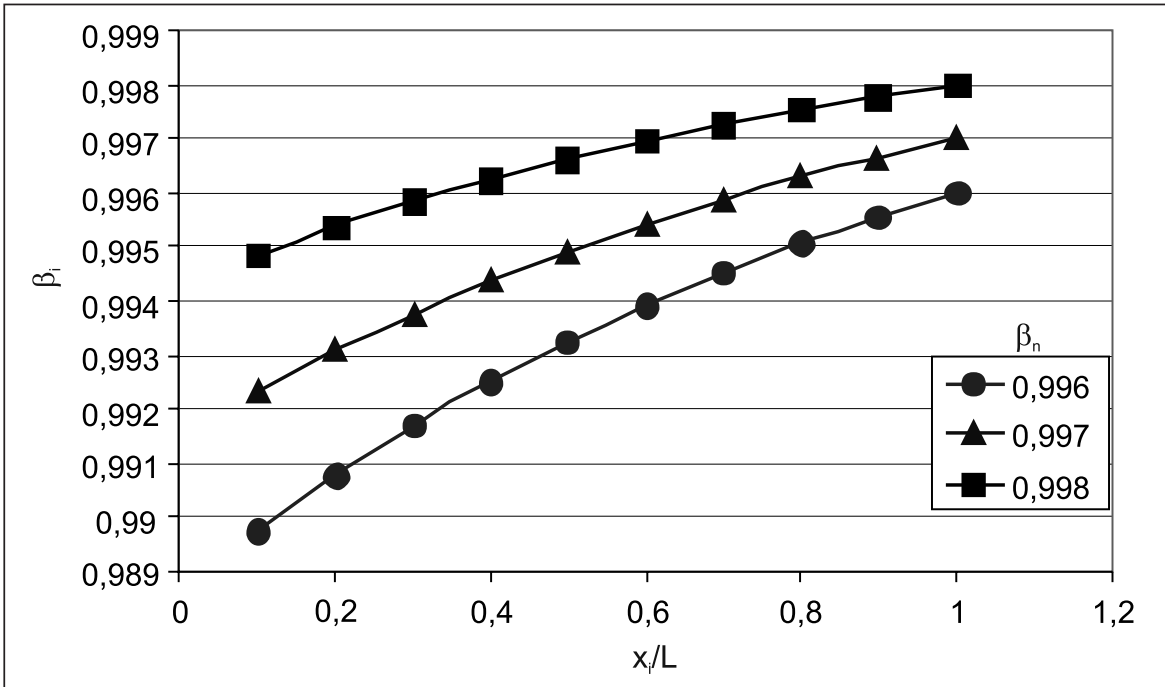

3 pav. Vidutinio tūrinio dujingumo kitimas pagal putų kanalo ilgi

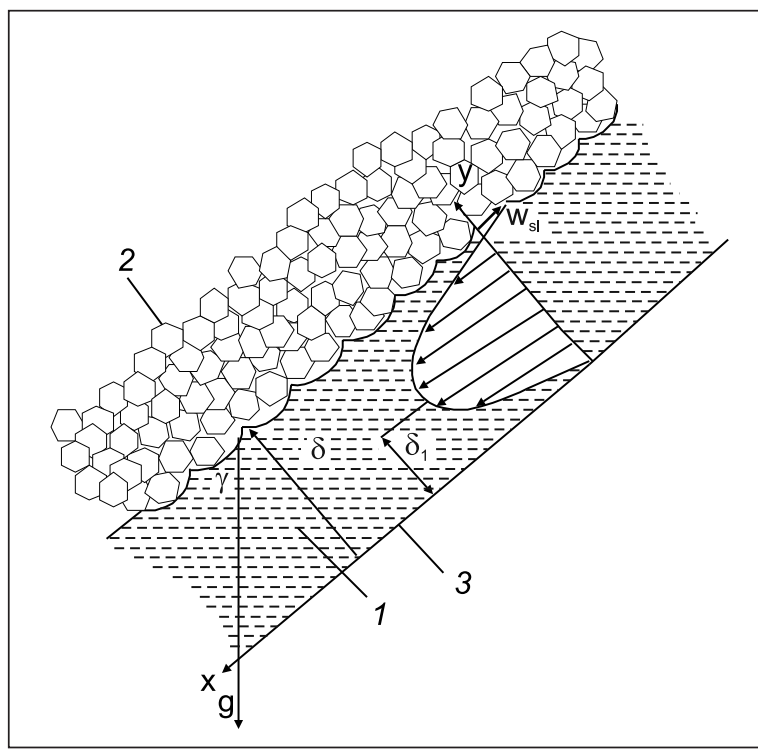

4 pav. Drenažinio tirpalo greičio profilis: 1 - tirpalas; 2 - putos; 3 - sienelè

Drenažinio tirpalo tekejjimo lygtis atrodytų taip:

$\rho_{l} \cdot g \cdot \cos \gamma+\mu_{l} \frac{d^{2} w_{l}}{d y^{2}}=0$

Šios lygties sprendinys $(\mathrm{m} / \mathrm{s})$ :

$$
w_{l}=A_{l} y\left[(\delta-y) \pm \frac{w_{s l}}{A_{l} \delta}\right]
$$

čia: $A_{l}=\frac{\rho_{l} \cdot g \cdot \cos \gamma}{2 \mu_{l}} ; w_{s l}-$ santykinis (slydimo) greitis randamas $(\mathrm{m} / \mathrm{s})$ :

$$
w_{s l}=\mp \frac{A_{l}}{12} \delta^{2}=\mp \frac{g \cdot \delta^{2}}{24 v_{l}} \cos \gamma .
$$

Tuomet pasrovio tekejjimo atveju (kai putos ir drenažinis tirpalas juda žemyn) gaunama $(\mathrm{m} / \mathrm{s})$ :

$$
w_{l}=\frac{A_{l} y}{12}(13 \delta-12 y) ;
$$

priešsrovio tekejjimo atveju (kai putos juda aukštyn, o drenažinis tirpalas - žemyn) gaunama $(\mathrm{m} / \mathrm{s})$ :

$$
w_{l}=\frac{A_{l} y}{12}(11 \delta-12 y) \text {. }
$$

Geometrinė $(12,13)$ lygčių interpretacija pavaizduota 5 pav.

Siekiant surasti drenažinio tirpalo sluoksnio storị $\delta(\mathrm{m})$, reikia žinoti tūrinị tirpalo debitą sluoksnyje, tenkantị vienam kanalo pločio metrui, $\mathrm{m}^{2} / \mathrm{s}$ :

$$
G_{l}=\int_{0}^{\delta} w_{l} d y=\int_{0}^{\delta} A_{l} y\left[(\delta-y) \pm \frac{w_{s l}}{A_{l} \delta}\right] d y=\frac{\delta}{6}\left(A_{l} \delta^{2} \pm 3 w_{s l}\right)
$$

Tirpalo debitas, tenkantis vienam kanalo pločio metrui $\left(\mathrm{m}^{2} / \mathrm{s}\right)$,

kai tekejjimo kryptys sutampa:

$G_{l}=\frac{\delta}{6}\left(A_{l} \delta^{2}+3 w_{s l}\right)=\frac{5}{24} A_{l} \delta^{3}$

kai tekejjimo kryptys priešingos:

$G_{l}=\frac{\delta}{6}\left(A_{l} \delta^{2}-3 w_{s l}\right)=\frac{3}{24} A_{l} \delta^{3}$.

Tada vidutinis masinis tirpalo debitas (kg/s), kai tekejjimo kryptis sutampa:

$$
G_{l, \Sigma d r, i}=\frac{5}{24} A_{l} \cdot a \cdot \delta_{i}^{3} \cdot \rho_{l}
$$

kai tekejjimo kryptys priešingos:

$$
G_{l, \sum d r, i}=\frac{3}{24} A_{l} \cdot a \cdot \delta_{i}^{3} \cdot \rho_{l} \text {. }
$$


(a)

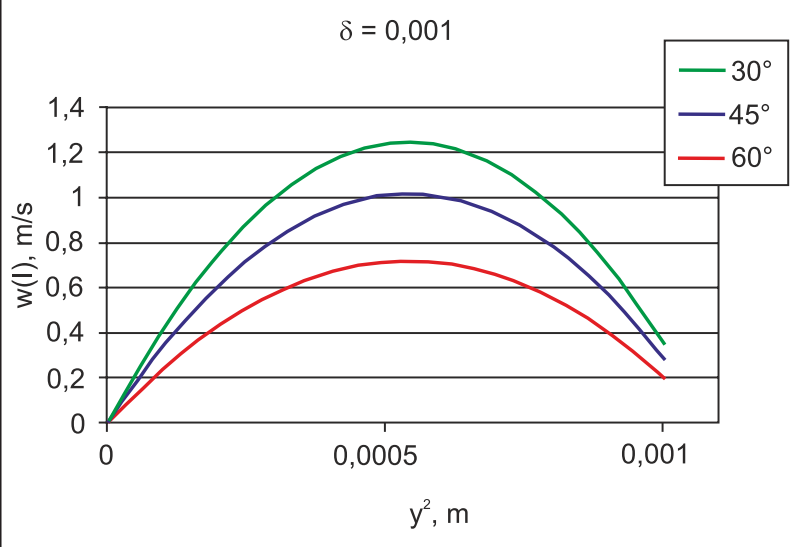

(b)

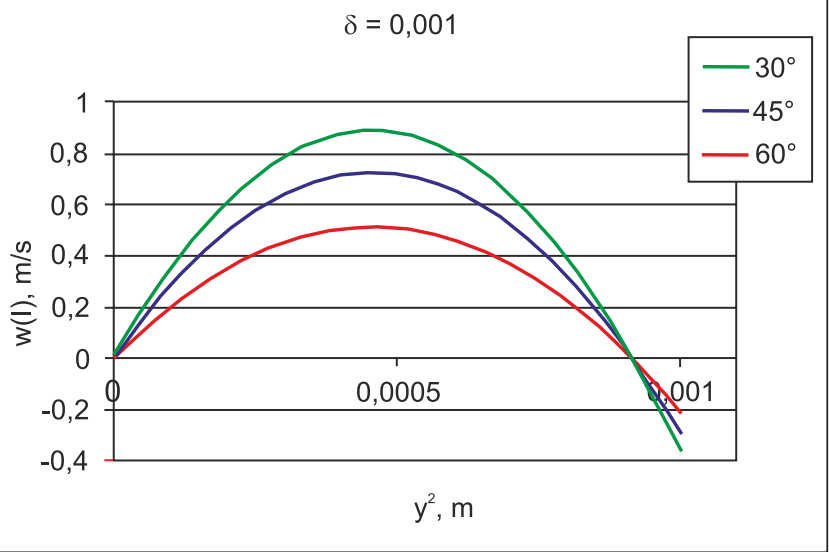

5 pav. Pasrovio (a) ir priešsrovio (b) tirpalo sluoksnio greičio profiliai

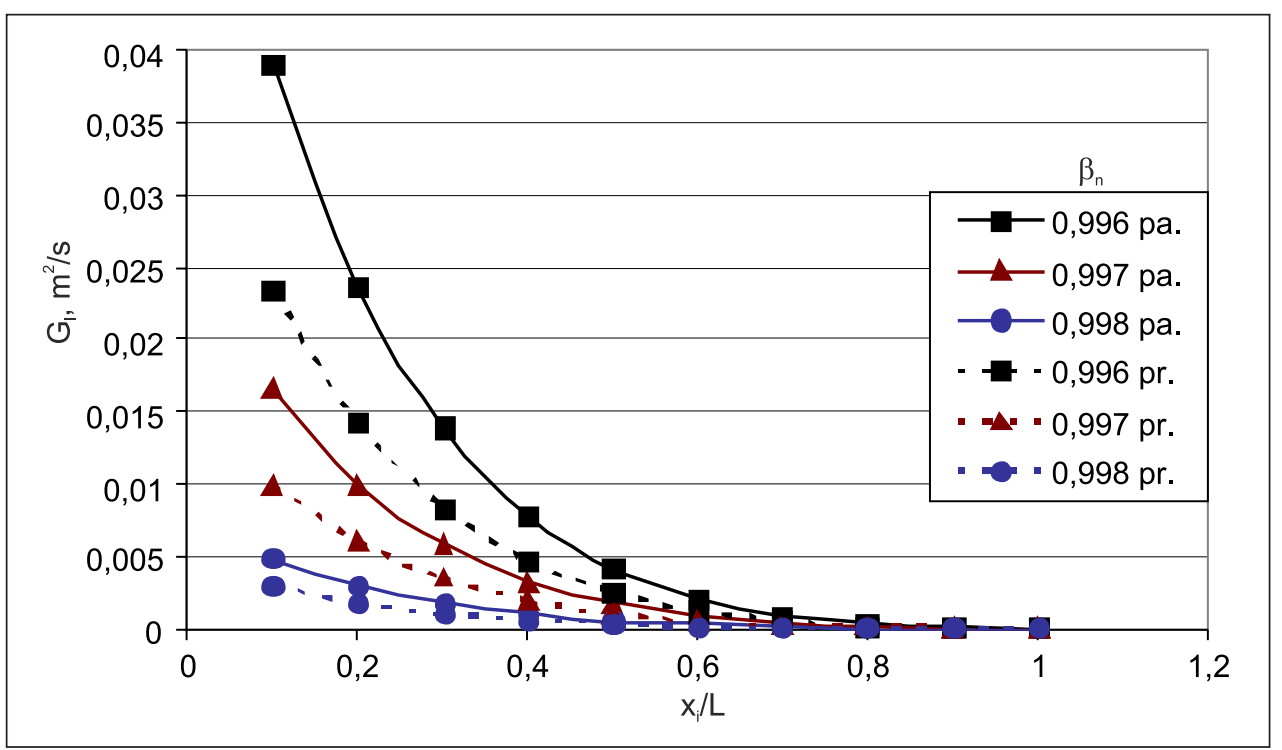

6 pav. Pasrovio (-- - ) ir priešsrovio (----) $\left(\gamma=45^{\circ} ; \bar{w}_{g}=0,2 \mathrm{~m} / \mathrm{s}\right)$ tirpalo debito kitimas eksperimentinio ruožo ilgyje

Lygčių $(17,18)$ geometriné interpretacija pateikta 6 pav.

Sulyginę (3) lygties ir (17), (18) lygčių dešiniąsias puses, išreiškiame drenažinio tirpalo sluoksnio storị (m), kai tekèjimo kryptys yra priešingos:

$$
\begin{aligned}
& \delta_{i}=2,52\left\{G_{g}\left(\frac{1-\beta_{n}}{\beta_{n}}\right) \frac{v_{l}}{\rho_{g} \cdot a \cdot g \cdot \cos \gamma}\right. \\
& \left.\left[\left(\frac{n-1}{n}\right)^{(i-n)}-\left(\frac{n-1}{n}\right)\right]\right\}^{0,333} ;
\end{aligned}
$$

kai tekejjimo kryptys sutampa:

$$
\begin{aligned}
& \delta_{i}=2,13\left\{G_{g}\left(\frac{1-\beta_{n}}{\beta_{n}}\right) \frac{v_{l}}{\rho_{g} \cdot a \cdot g \cdot \cos \gamma}\right. \\
& \left.\left[\left(\frac{n-1}{n}\right)^{(i-n)}-\left(\frac{n-1}{n}\right)\right]\right\}^{0,333} .
\end{aligned}
$$

Geometrinè $(19,20)$ lygčių interpretacija pateikta 7 pav.

\section{Šilumos atidavimas}

Supaprastinta pasvirusio putų kanalo su apatiniu plokščiu kaitinimo paviršiumi schema pavaizduota 8 pav.

Nustatant plokščio pasvirusio paviršiaus šilumos atidavimo putų srautui intensyvumą, be hidrodinaminių drenažinio tirpalo sluoksnio parametru, taip pat būtina žinoti kaitinimo paviršiaus temperatūrą (nustatoma eksperimentiškai) bei tirpalo temperatūros kitimą išilgai kaitinimo paviršiaus (apskaičiuojama).

Nustatydami tirpalo sluoksnio temperatūrą, pasinaudosime šilumos balanso lygtimi. Tokiu atveju iš $i$-tosios zonos ištekančio tirpalo temperatūra $\left({ }^{\circ} \mathrm{C}\right)$ :

$$
T_{l, i_{i s}}=T_{l, d r . i}+\frac{q \cdot l_{i}}{\Delta G_{l, i} \cdot c_{p l, i}},
$$

čia: $c_{p l, i}$ - tirpalo savitoji šiluma, $\mathrm{kJ} /(\mathrm{kg} \mathrm{K}) ; q$ - šilumos srauto tankis, $\mathrm{W} / \mathrm{m}^{2} ; T_{l, d r, i}-\mathrm{i} i$-ąją zoną atitekančio drenažinio 


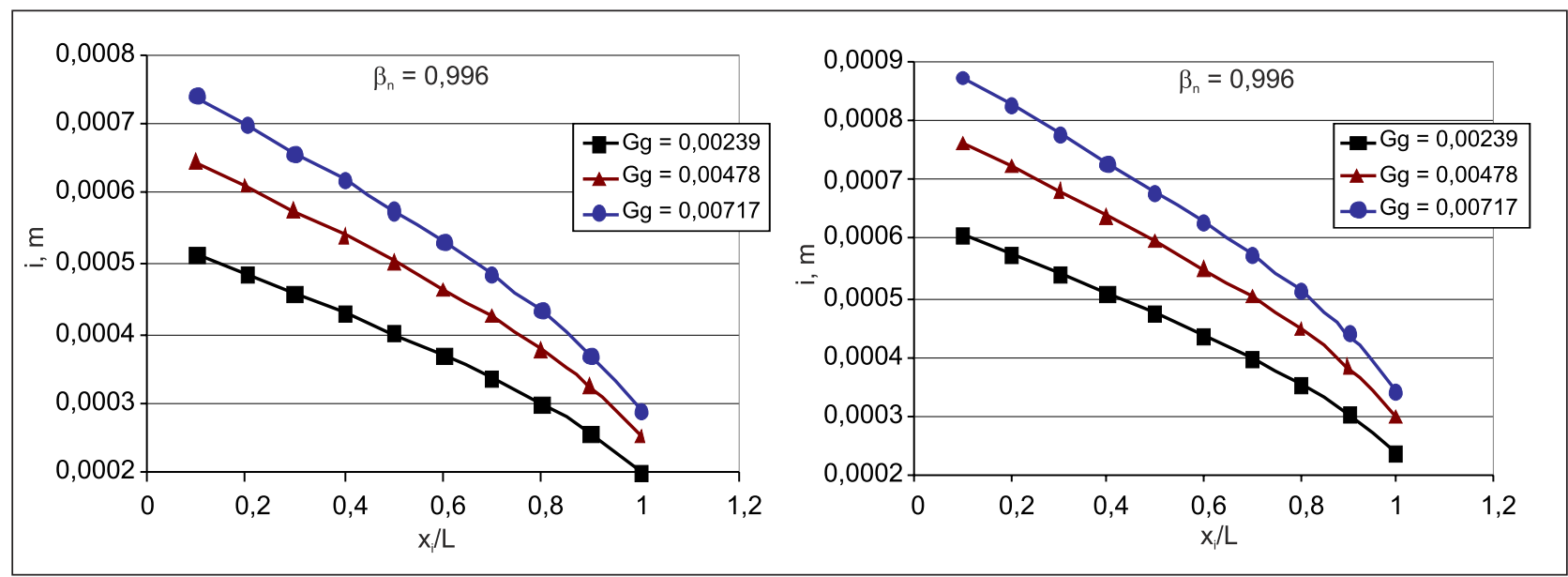

7 pav. Tirpalo sluoksnio storio kitimas esant skirtingiems oro debitams (vidutinis dujingumas $\beta=0,996$ )

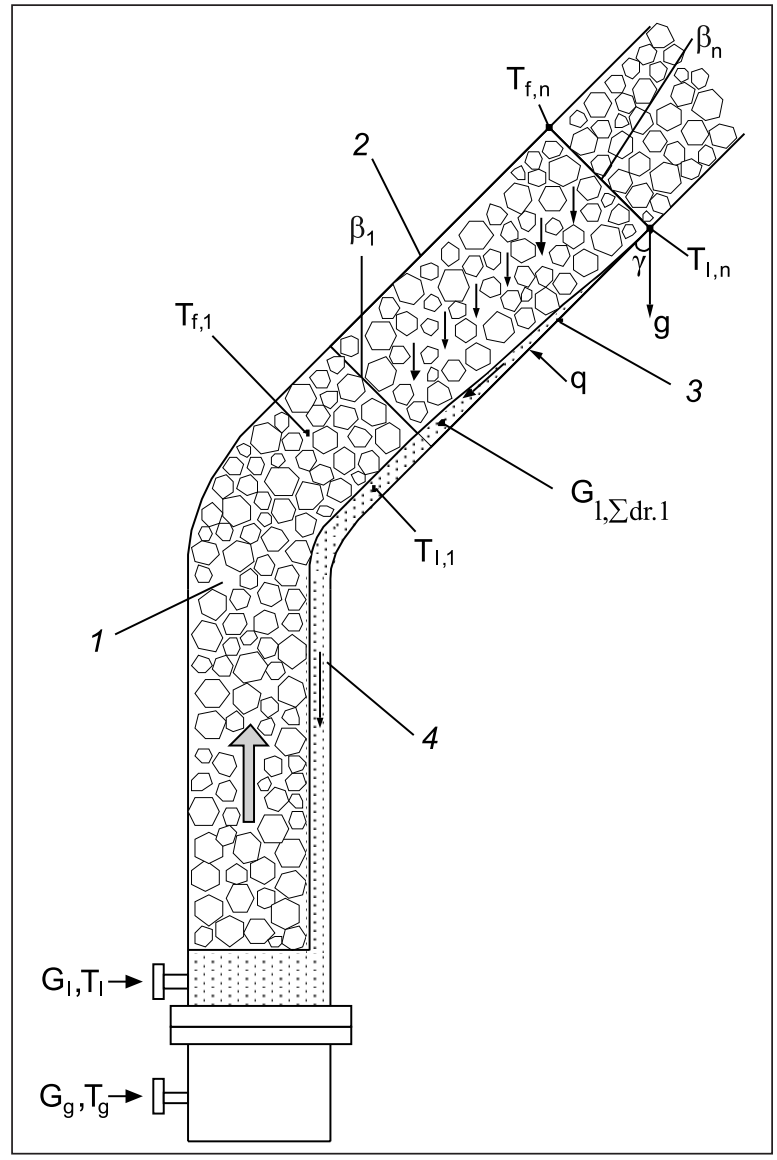

8 pav. Supaprastinta pasvirusio putų kanalo schema: 1 - putų srautas; 2 - eksperimentinis ruožas; 3 - plokščias kaitinimo paviršius; 4 - drenažinio tirpalo sluoksnis

tirpalo bei $i$-ojoje zonoje nusidrenavusio tirpalo vidutinè temperatūra $\left({ }^{\circ} \mathrm{C}\right)$ nustatoma:

$$
T_{l, d r . i}=\frac{\Delta G_{l,(i+1)} \cdot T_{l,(i+1)_{s, s}}+G_{l, d r . i} \cdot T_{f, 2}}{G_{l, i}},
$$

čia $T_{f, 2}-$ putų srauto temperatūra, ${ }^{\circ} \mathrm{C}$.
Drenažinio tirpalo temperatūros kitimas išilgai eksperimentinio ruožo pavaizduotas 9 pav.

Vidutinị $i$-ojoje zonoje šilumos atidavimo koeficientą randame pasinaudodami šilumos perdavimo ir šilumos balanso lygtimis.

Putoms perduodama šilumos galia nustatoma iš šilumos perdavimo lygties $(\mathrm{kW})$ :

$$
Q=\alpha_{i} \cdot\left(T_{w, i}-T_{l, i}^{v i d}\right) \cdot F_{w, i},
$$

čia: $\alpha_{i}$ - vidutinis šilumos atidavimo koeficientas $i$-ojoje zonoje, $\mathrm{W} /\left(\mathrm{m}^{2} \mathrm{~K}\right) ; F_{w, i}-i$-osios zonos kaitinimo paviršiaus plotas, $\mathrm{m}^{2} ; T_{l, i}$ vid. - vidutiné tirpalo temperatūra $i$-ojoje zonoje, ${ }^{\circ} \mathrm{C}$.

Eksperimento metu nustatytas kaitinamo paviršiaus temperatūros $T_{w, i}$ kitimas pavaizduotas 10 pav.

Šilumos galią galima surasti ir iš balanso lygties (įvertinamas tiktai su putomis pernešamo tirpalo debitas), $\mathrm{kW}$ :

$$
\begin{aligned}
& \Delta G_{l,(i+1)} \cdot c_{p_{l}} \cdot T_{l,(i+1)_{i s}}+G_{l, i d r .} \cdot c_{p l} \cdot \\
& \cdot T_{f, 2}+Q_{k a r t, i}=\Delta G_{l, i} \cdot c_{p l} \cdot T_{l, i, i s},
\end{aligned}
$$

čia:

$$
\begin{aligned}
& Q=Q_{\text {kait }, i}=c_{p_{l}}\left(\Delta G_{l, i} \cdot T_{l, i_{i s}}-\right. \\
& \left.-\Delta G_{l,(i+1)} \cdot T_{l,(i+1)_{i s}}-G_{l, i d r} \cdot T_{f, 2}\right),
\end{aligned}
$$

čia: $Q_{\text {kait, }, i}$ - kaitinimo paviršiaus tirpalo srautui $i$-ojoje zonoje suteiktos šilumos galia, $\mathrm{kW}$.

Kadangi:

$\Delta G_{l, i}=\Delta G_{l,(i+1)}+G_{l, i d r}$

tai lygtis (25) atrodys taip: 


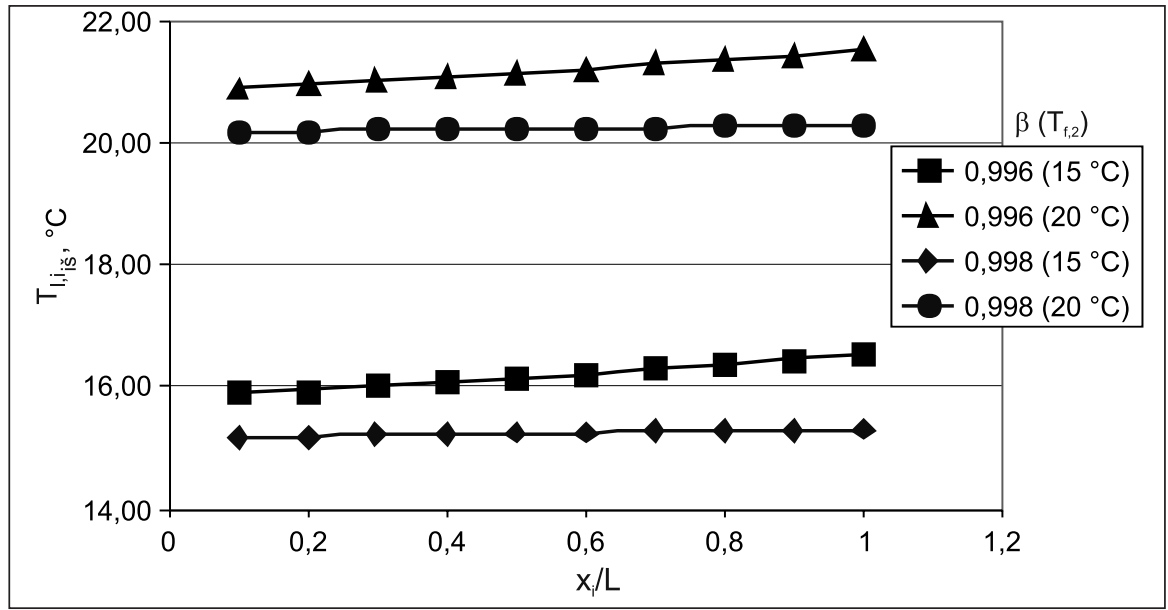

9 pav. Nusidrenavusio tirpalo temperatūros kitimas išilgai eksperimentinio ruožo $\left(\bar{w}_{g}=0,2 \mathrm{~m} / \mathrm{s}\right)$

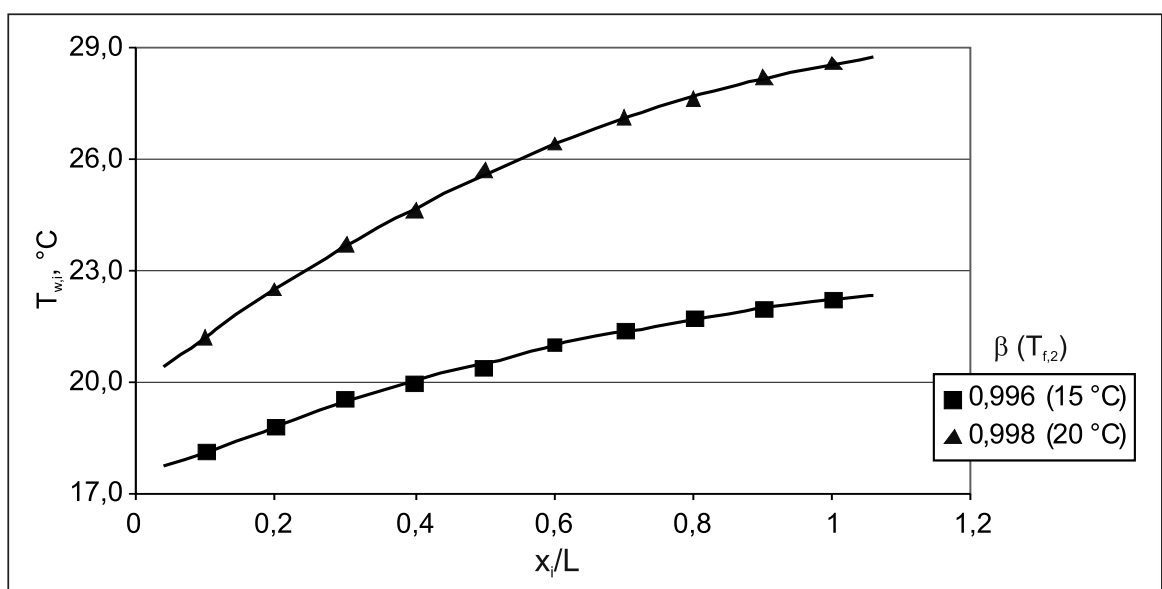

10 pav. Eksperimentinio ruožo (kaitinimo paviršiaus) temperatūros kitimas (eksperimentiniai duomenys)

$Q=c_{p_{l}}\left(\Delta G_{l,(i+1)} \cdot T_{l, i_{i j}}+G_{l, i d r .} \cdot T_{l, i_{i s}-}\right.$

$\left.-\Delta G_{l,(i+1)} \cdot T_{l,(i+1)_{l i s}}-G_{l, i d r} \cdot T_{f, 2}\right)$

arba:

$Q=c_{p_{l}}\left[\sum G_{l,(i+1)}\left(T_{l, i_{i s}}-T_{l,(i+1)_{i s}}\right)+G_{l, i d r .}\left(T_{l, i_{i s}}-T_{f, 2}\right)\right]$.

Iš $(23,28)$ lygčių nustatome šilumos atidavimo koeficientą, $\mathrm{W} / \mathrm{m}^{2} \mathrm{~K}$ :

$\alpha_{i}=\frac{\Delta G_{l,(i+1)} \cdot c_{p_{l}}\left(T_{l, i_{i s}}-T_{l,(i+1)_{i j}}\right)}{F_{w, i} \cdot\left(T_{w, i}-T_{l, i}^{v i d}\right)}+$

$+\frac{G_{l, i d r .} \cdot c_{p_{l}}\left(T_{l, i_{i s}}-T_{f, 2}\right)}{F_{w, i} \cdot\left(T_{w, i}-T_{l, i}^{v i d}\right)}$

arba

$\alpha_{i}+\alpha_{i, \Sigma}+\alpha_{i, d r}$

čia:

$$
\left.\begin{array}{l}
\alpha_{i, \Sigma}=\frac{\Delta G_{l,(i+1)} \cdot c_{p_{l}}}{F_{w, i}} \cdot \frac{\left(T_{l, i_{i s}}-T_{\left.l,(i+1)_{s}\right)}\right)}{\left(T_{w, i}-T_{l, i}^{v i d}\right)} \\
\alpha_{i, d r}=\frac{G_{l, i d r .} \cdot c_{p_{l}}}{F_{w, i}} \cdot \frac{\left(T_{l, i_{i s}}-T_{f, 2}\right)}{\left(T_{w, i}-T_{l, i}^{v i d .}\right)}
\end{array}\right\} .
$$

Šilumos atidavimo koeficientas $\alpha_{i, \Sigma}$ charakterizuoja nusidrenavusio tirpalo sluoksnio pašilimo intensyvumą $i$-ojoje zonoje, o šilumos atidavimo koeficientas $\alpha_{i, d r}$ charakterizuoja $i$-ojoje zonoje besidrenuojančio tirpalo pašilimo intensyvumą.

Lygti (30) galima perrašyti taip:

$\alpha_{i}=\alpha_{i, l} \frac{\Delta T_{l, i}}{\Delta \vartheta_{i}}+\alpha_{i, f} \frac{\Delta T_{l, i d r .}}{\Delta \vartheta_{i}}$,

čia:

$$
\begin{aligned}
& \alpha_{i, l}=\frac{\Delta G_{l,(i+1)} \cdot c_{p_{l}}}{F_{w, i}} ; \alpha_{i, f}=\frac{G_{l, i d r} \cdot c_{p_{l}}}{F_{w, i}} ; \Delta T_{l, i}=\left(T_{l, i}-T_{l,(i+1)_{i s}}\right) ; \\
& \Delta T_{l, i d r:}=\left(T_{l, i_{i s}}-T_{f, 2}\right) ; \Delta \vartheta_{i}=\left(T_{w, i}-T_{l, i}^{v i d}\right) ; T_{l, i}^{v i d}=\frac{T_{l,(i+1)_{i s}}+T_{l, i_{i s}} .}{2}
\end{aligned}
$$

Geometrinè (29) lygties interpretacija pateikta 11 pav. 


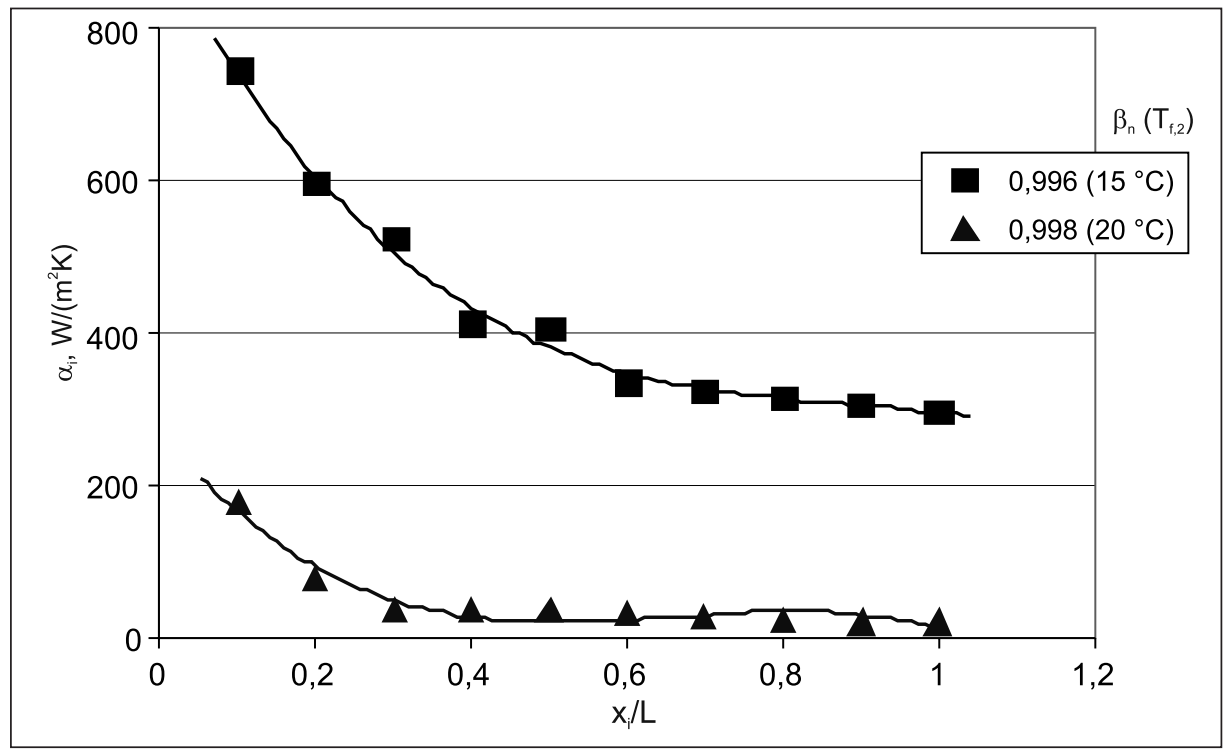

11 pav. Šilumos atidavimo koeficiento $a_{i}$ kitimas išilgai eksperimentinio ruožo $\left(\bar{w}_{g}=0,2 \mathrm{~m} / \mathrm{s}\right)$

\section{EKSPERIMENTINIAI TYRIMAI}

Pasvirusiame eksperimentinio kanalo ruože (12 pav.) išilgai vidinès apatinès kanalo sienelès sumontuotas ploǩčias, elektros srove kaitinamas paviršius. Iš nerūdijančio plieno pagaminto plokščio paviršiaus ilgis $-0,5 \mathrm{~m}$, plotis $-0,12 \mathrm{~m}$, o storis $-0,1 \mathrm{~mm}$. Prie plokščio paviršiaus trimis išilginèmis eilèmis pritvirtinta aštuoniolika vario-konstantano ter- moporų (po šešias kiekvienoje eilèje), kurių išèjimo signalai realiu laiku per duomenų kaupikli perduodami $\mathfrak{i}$ kompiuterị ir įrašomi ị duomenų bazę. Atstumai tarp termoporų: išilgine kryptimi - $80 \mathrm{~mm}$, skersine - $40 \mathrm{~mm}$. Itampos kritimas ant kaitinamo plokščio paviršiaus gnybtų matuotas voltmetru, o sroves stipris - ampermetru, parodymus nurodant jų skalèse ir periodiškai registruojant - ịvedant $\mathfrak{i}$ kompiuterio duomenų bazę.

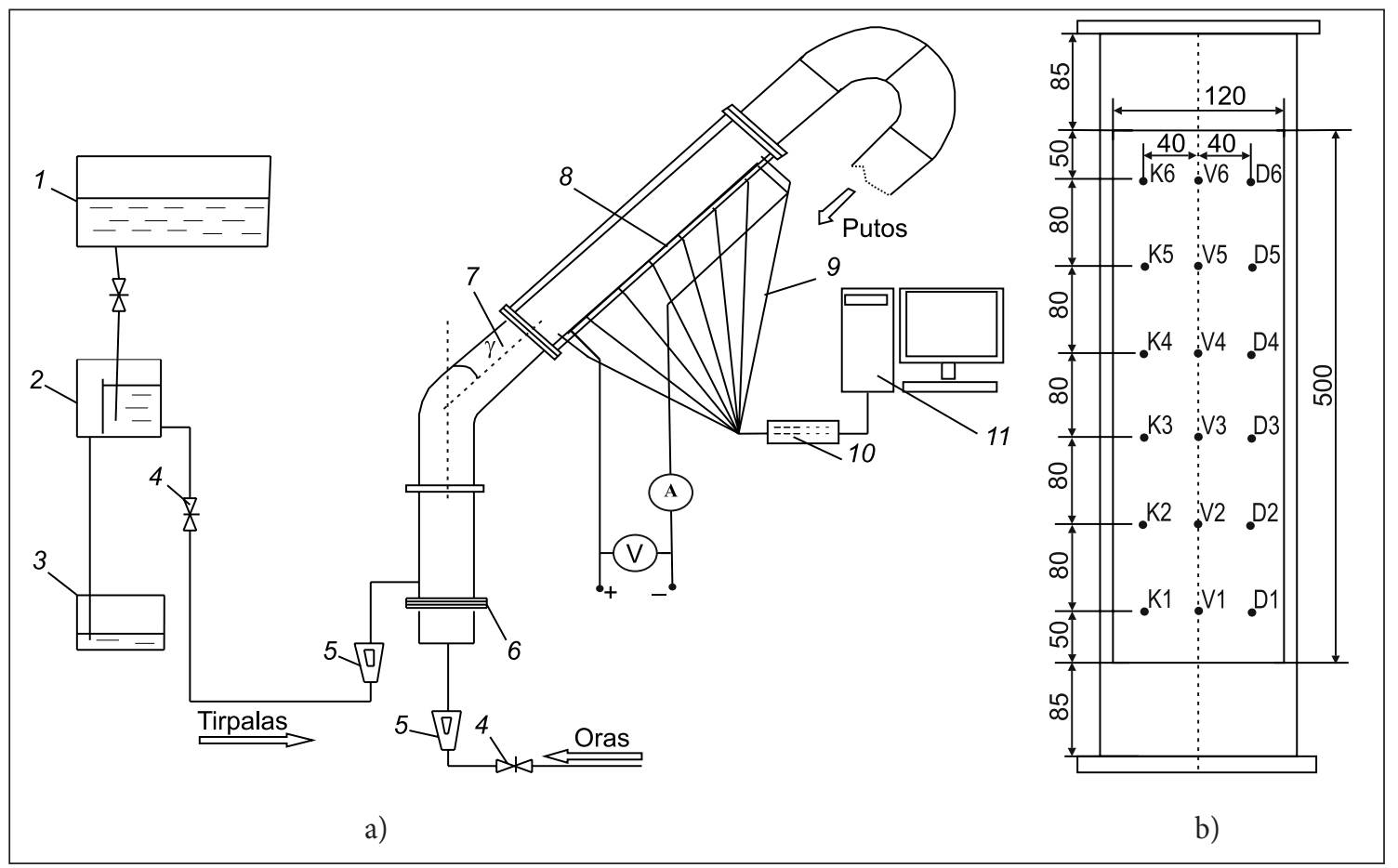

12 pav. Eksperimentinio stendo (a) ir kaitinimo plokštes (b) schema: 1 - tirpalo rezervuaras; 2 - pastovaus lygio palaikymo rezervuaras; 3 - tirpalo pertekliaus surinkimo rezervuaras; 4 - debito reguliavimo ventilis; 5 - debitomatis; 6 - perforuota putų generavimo plokštelè; 7 - eksperimentinio kanalo ruožas su įmontuotu plokščiu paviršiumi; 8 - plokščias paviršius; 9 - termoporos; 10 - duomenų kaupikliai; 11 - kompiuteris 
Plokščias paviršius aušinamas jị išilgai aptekančių dvifazių statiškai stabilių putų srautu. Šilumos atidavimo koeficiento vertès $\mathrm{W} /\left(\mathrm{m}^{2} \mathrm{~K}\right)$ esant nusistovejjusiam šiluminiam režimui eksperimentiniame ruože nustatomos taip:

$$
\alpha=\frac{q_{w}}{\Delta T}=\frac{U I}{A_{p l} \Delta T},
$$

čia: $q_{w}$ - plokščio paviršiaus atiduodamos šilumos srauto tankis, $\mathrm{W} / \mathrm{m}^{2} ; \Delta T$ - temperatūrų skirtumas tarp plokščio paviršiaus temperatūros ir tirpalo temperatūros drenažinio skysčio plèvelejje ties ta pačia plokščio paviršiaus vieta, K; $U$ - ittampa ant kaitinamojo plokščio paviršiaus gnybtų, V; I - plokščiu paviršiumi tekančios elektros srovės stipris, $\mathrm{A} ; A_{p l}$ - plokščio paviršiaus plotas (mūsų atve$\left.\mathrm{ju}-A_{p l}=0,5 \times 0,12=0,06\right), \mathrm{m}^{2}$.

Vidutinis skersine paviršiaus kryptimi šilumos atidavimo koeficientas randamas laikant, kad vidutinė paviršiaus temperatūra skersine kryptimi yra lygi trijų termoporų, išdėstytų skersine srautui kryptimi, parodymų vidurkiui.

Eksperimentinių tyrimų sąlygos: putų tūrinis debitinis dujingumas $\beta=0,996,0,997$ ir 0,998 , putų srauto greitis $w=0,1-0,25 \mathrm{~m} / \mathrm{s}$, kai $\beta=0,996$ ir 0,997 ir $w=0,1-0,3 \mathrm{~m} / \mathrm{s}$, kai $\beta=0,998$; ị eksperimentinị stendą tiekiamo oro debitas $G_{g}=1,96 \cdot 10^{-3}-5,90 \cdot 10^{-3} \mathrm{~m}^{3} / \mathrm{s}$; tiekiamo tirpalo debitas $G_{l}=3,93 \cdot 10^{-6}-19,76 \cdot 10^{-6} \mathrm{~m}^{3} / \mathrm{s}$; per kaitinamą paviršių tekančios srovès stipris: $I=64,5 \pm 0,5 \mathrm{~A}$; ittampos kritimas ant gnybtų $U=1,55 \pm 0,02 \mathrm{~V}$; kaitinimo galia $Q=1500-1800 \mathrm{~W} / \mathrm{m}^{2}$; kanalo posvyrio kampas $\gamma=45^{\circ}$.

\section{TYRIMO REZULTATAI}

Straipsnyje pateikiami rezultatai, gauti tiriant vidutinio skersine kryptimi šilumos atidavimo koeficiento kitimą išilgai eksperimentinio ruožo, esant skirtingam putų srauto greičiui bei dujingumui. Eksperimentinių tyrimų rezultatai grafiškai pavaizduoti 13 pav.

Plokščio pasvirusio paviršiaus šilumos atidavimo putų srautui intensyvumas mažeja išilgai eksperimentinio ruožo putų tekejjimo kryptimi, nes besidrenuojant iš putų srauto tirpalui putos sausėja ir tuomet blogiau aušina paviršių. Mažèjant putų srauto dujingumui (drègnèjant putoms) šilumos atidavimo koeficientas didejja.

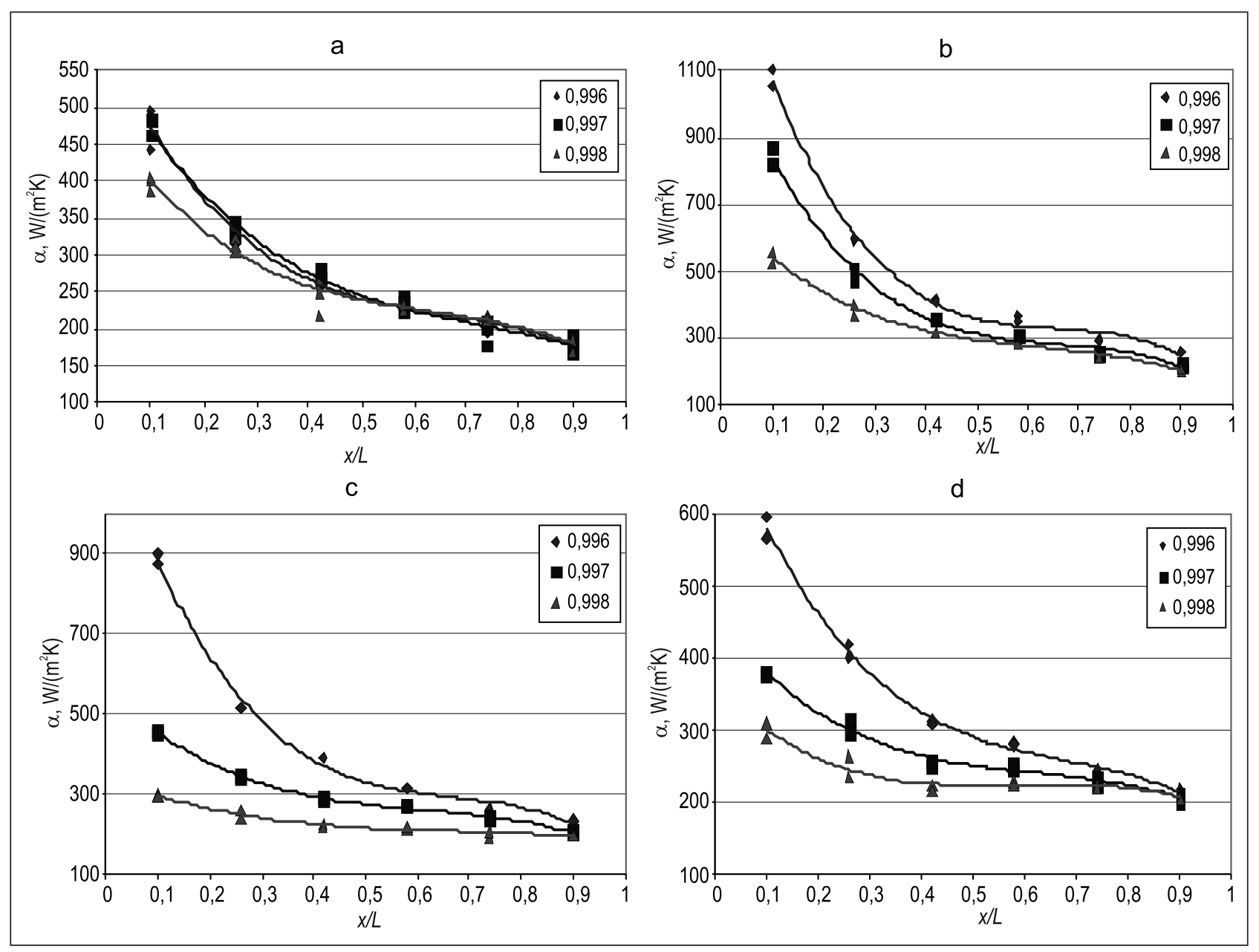

13 pav. Plokščio paviršiaus aušinimo intensyvumo kitimas išilgai paviršiaus, kai putų srauto greitis $w(\mathrm{~m} / \mathrm{s}): \mathrm{a}-0,1 ; \mathrm{b}-0,15 ; \mathrm{c}-0,2 ; \mathrm{d}-0,25$ ir $\beta=0,996,0,997$ ir 0,998 


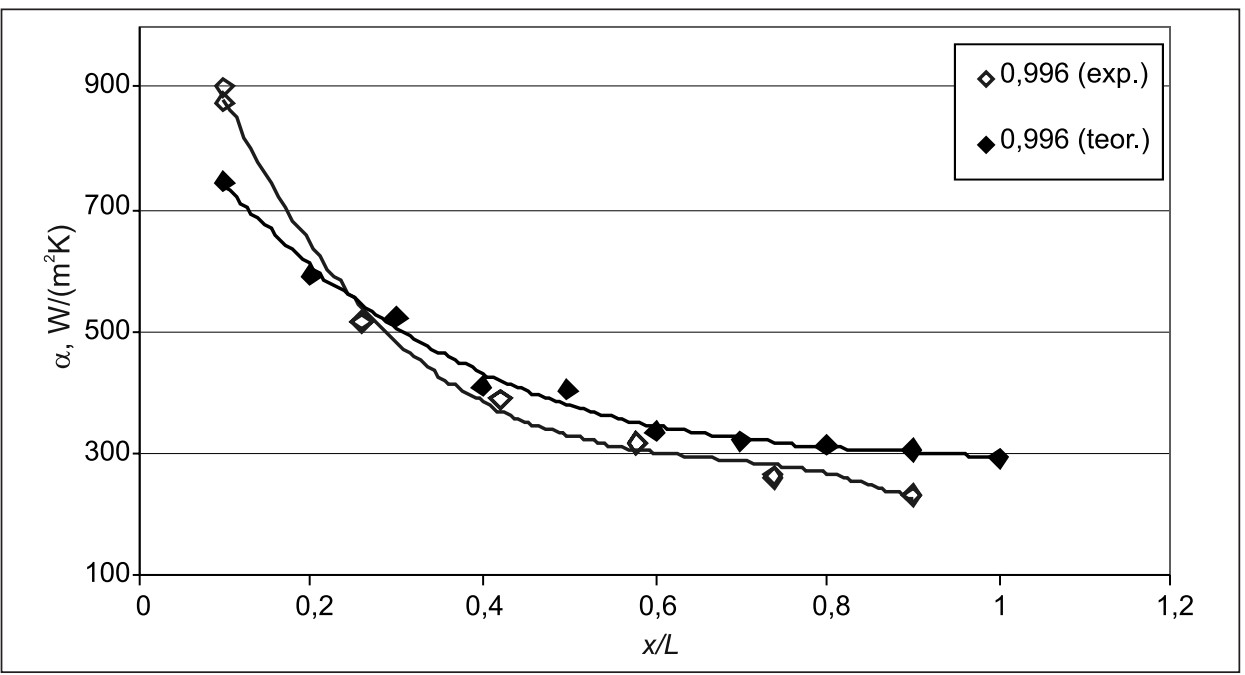

14 pav. Plokščio paviršiaus aušinimo intensyvumo kitimas išilgai paviršiaus, kai putų $w=0,2 \mathrm{~m} / \mathrm{s}$ ir $\beta=0,996$

Teorinių ((29)-(32) lygtys) bei eksperimentinių tyrimų rezultatų palyginimas pateiktas 14 pav. Rezultatų nesutapimas yra mažesnis kaip $25 \%$, kas dvifazių putų srautų atveju yra priimtina.

Eksperimentiškai nustatytas taip pat ir vidutinis $45^{\circ}$ kampu pasvirusio plokščio paviršiaus šilumos atidavimo koeficientas. 15 pav. pateikta šio koeficiento priklausomybẻ nuo putų srauto greičio, kai putų dujingumas $\beta=0,996$; 0,997 ir 0,998 .

Didejjant putu srauto greičiui paviršiaus vidutinio šilumos atidavimo koeficiento verte dideja iki tam tikro maksimalaus dydžio, priklausančio nuo putų srauto dujingumo. Toliau didinant putų srauto greitį aušinimo intensyvumas mažèja. Maksimali šilumos atidavimo koe- ficiento vertė yra didesnè ir pasiekiama esant didesniam greičiui tada, kai putų srautas yra drégnesnis (mažesnis dujingumas). Be to, didejjant putų srauto greičiui nuo $w=0,1 \mathrm{~m} / \mathrm{s}$ iki $w=0,137 \mathrm{~m} / \mathrm{s}$ šilumos atidavimo intensyvumas beveik nepriklauso nuo putų dujingumo (skirtumas nesiekia $8 \%$ ).

Tokį neịprastą šilumos atidavimo intensyvumo kitimą, priklausomai nuo putų srauto greičio, galima paaiškinti.

Putoms tekant pasvirusiu eksperimentiniu kanalu ant kaitinimo paviršiaus formuojasi drenažinio tirpalo sluoksnis. Veikiamas sunkio jègos, sluoksnyje esantis tirpalas juda žemyn. Didejjant putų srauto greičiui didèja putų srauto poveikis ị priešinga kryptimi tekančio tirpalo srautą.

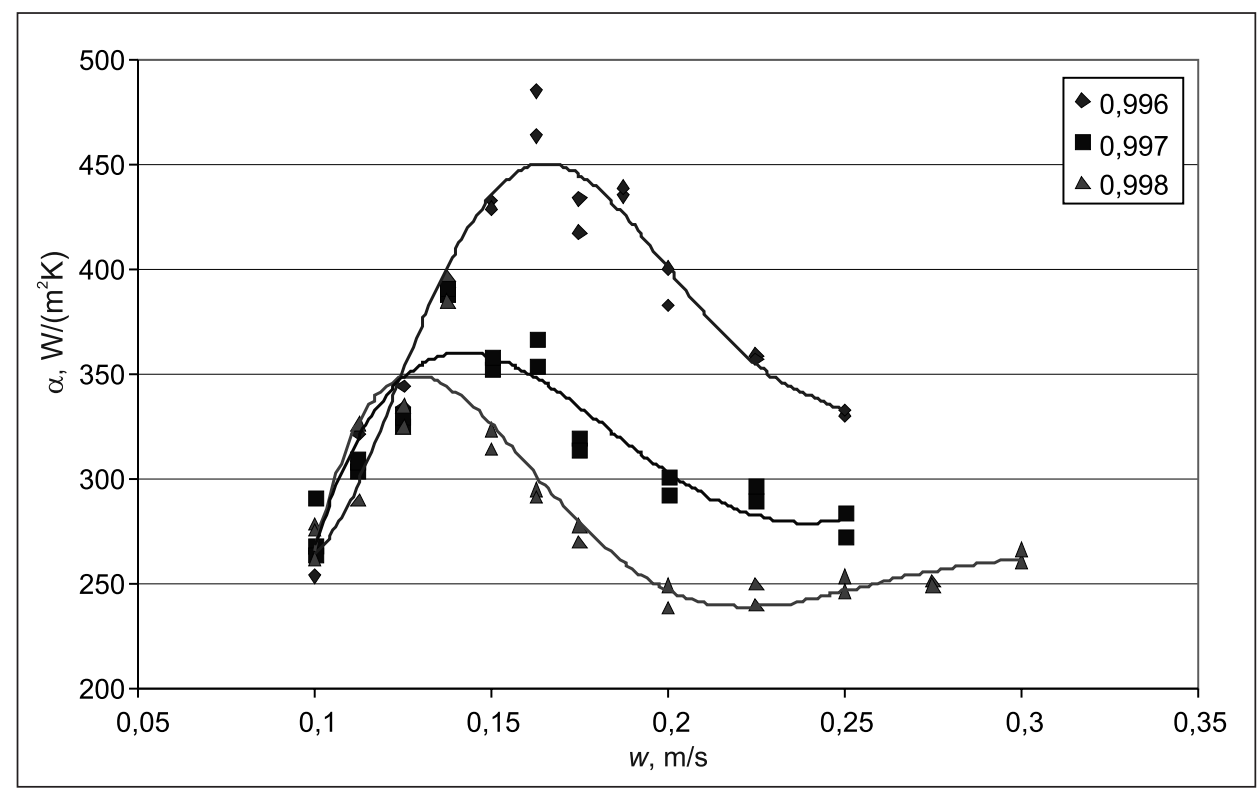

15 pav. Pasvirusio plokščo paviršiaus vidutinio šilumos mainų putų sraute intensyvumo priklausomybè nuo putu srauto greičio, kai $\beta=0,996 ; 0,997$ ir 0,998 
Toliau didejjant putų srauto greičiui tirpalo srautas keičia kryptí, ima tekèti, „tempiamas“ putų srauto ta pačia kryptimi (ị viršų). Pasiekus pakankamai dideli putų srauto greitị, kartu padideja ir tirpalo greitis sluoksnyje, sumažèja sluoksnio storis ir šilumos atidavimo intensyvumas vèl ima augti (15 pav. apatine kreivè). Drenažinio tirpalo srautas keičia tekejjimo kryptị tuo greičiau (esant mažesniam putų srauto greičiui), kuo didesnis putų dujingumas (mažesnis nusidrenavusio tirpalo sluoksnis).

\section{IŠVADOS}

1. Pasvirusio plokščio paviršiaus aušinimo putų srautu intensyvumą lemia ant paviršiaus susiformavusio iš putų nusidrenavusio tirpalo sluoksnio storis, tirpalo greitis drenažiniame sluoksnyje ir tirpalo temperatūra. Šie parametrai priklauso nuo paviršiaus posvyrio kampo, putų temperatūros, debito ir dujingumo.

2. Plokščio pasvirusio paviršiaus šilumos atidavimo putų srautui intensyvumas mažèja išilgai eksperimentinio ruožo putų tekejjimo kryptimi, nes besidrenuojant iš putų srauto tirpalui putos sausèja ir blogiau aušina paviršių.

3. Didejjant putu srauto greičiui paviršiaus vidutinio šilumos atidavimo koeficiento vertè didejja iki tam tikro maksimalaus dydžio, priklausančio nuo putų srauto dujingumo. Toliau didinant putų srauto greitị aušinimo intensyvumas mažèja. Maksimali šilumos atidavimo koeficiento vertė yra didesnè ir pasiekiama esant didesniam greičiui tada, kai putų srautas yra drégnesnis (mažesnis dujingumas).

Gauta 20121130

Priimta 20121220

\section{Literatūra}

1. Жукаускас А. Конвективный перенос в теплообменниках. Москва: Наука, 1982. 472 с.

2. Kuppan T. Heat Exchanger Design Handbook. New York: Marcel Dekker, 2000. 1119 p.

3. Kaji M., Sawai T., Kagi Y., Ueda T. Heat transfer and fluid dynamics of air-water two phase flow in microchannels. Experimental Thermal and Fluid Science. 2010. Vol. 34. No. 4. P. 446-453.

4. Wu J., Koettig T., Franke Ch., Helmer D., Eisel T., Haug F., Bremer J. Investigation of heat transfer and pressure drop of $\mathrm{CO}_{2}$ two-phase flow in a horizontal minichannel. International Journal of Heat and Mass Transfer. 2011. Vol. 54. No. 9-10. P. 2154-2162.

5. Chang S. W., Yang T. L. Forced convective flow and heat transfer of upward cocurrent air-water slug flow in vertical plain and swirl tubes. Experimental Thermal and Fluid Science. 2009. Vol. 33. No. 7. P. 1087-1099.
6. Gylys J. Hidrodinamika, šilumos ir masés mainai statǐ̌kai stabiliu putu sistemose. Kaunas, 1998. 388 p.

7. Gylys J., Sinkunas S., Zdankus T. Experimental study of staggered tube bundle heat transfer in foam flow. Proceedings of the 5th International Symposium on Multiphase Flow, Heat Transfer and Energy Conversion, ISMF'05, 2005, Xi'an, China. P. 1-6.

8. Jakubčionis M. Šachmatinio vamzdžiu pluošto šilumos atidavimas kylančiame skersiniame putu sraute. Daktaro disertacija. Kaunas, 2002. 102 p.

9. Sinkunas S., Gylys J., Sunden B., Gabrielaitiene I., Zdankus T. Peculiarities of heat transfer from in-line tube bundles to upward aqueous foam flow. In: Sunden B., Brebbia C. A. (eds.). Advanced Computational Methods and Experiments in Heat Transfer X. 2008. P. 117-125.

10. Giedraitis V. Koridorinio vamzdžiu pluošto šilumos mainai vertikaliame statiškai stabiliu putu sraute. Daktaro disertacija. Kaunas, 2007. 119 p.

11. Gylys J., Zdankus T., Ingilertas A., Gylys M., Babilas M. Heat transfer between the non-standard tube bundle and statically stable foam flow. Mechanika. 2012. Vol. 18. No. 4. P. 409-414.

12. Ingilertas A. Nestandartinio vamzdžiu pluošto šilumos atidavimas statiškai stabiliu puty srautui. Daktaro disertacija. Kaunas, 2012. 124 p.

13. Gylys J., Gabrielaitienė I., Ždankus T., Jonynas R., Gylys M. Plokščio paviršiaus šilumos mainų dvifaziame putų sraute eksperimentinis tyrimas. Šilumos energetika ir technologijos - 2011: konferencijos pranešimų medžiaga. Kaunas: Technologija. 2011. P. 128-133.

14. Kurnia J. C., Sasmito A. P., Mujumdar A. S. Numerical investigation of laminar heat transfer performance of various cooling channel designs. Applied Thermal Engineering. 2011. Vol. 31. No. 6-7. P. 1293-1304.

15. Тихомиров В. К. Пены. Теория и практика их получения и разрушения. Москва: Химия. 1983. 262 с.

16. Sadoc J. F., Rivier N. Foams and Emulsions. Nato ASI Series. London: Kluwer Academic Press, 1997. 596 p.

17. Schramm L. L. Emulsions, Foams, and Suspensions. Weinheim: Wiley-VCH, 2005. 463 p.

\section{Martynas Gylys}

\section{INCLINED FLAT SURFACE COOLING BY TWO-PHASE FOAM FLOW}

\section{Summary}

The results of the experimental and analytical investigation of the heat transfer between the inclined flat surface and the statically stable foam flow are presented. On the inclined surface a film of the drained liquid is formed, which parameters - film thickness, liquid velocity, flow rate and temperature - influence the intensity of cooling. Drained liquid film parameters depend on the foam flow 
rate, void fraction and temperature. The analytical equations were proposed for the calculation of the liquid film thickness, flow rate, mean flow velocity and temperature. It was stated that the intensity of cooling rises with increase of the foam flow velocity, reaches its maximum value and goes down. Comparison of the analytical and experimental results showed a good agreement.

Key words: two-phase foam flow, inclined flat surface, drained liquid film, heat transfer
Мартинас Гилис

\section{ОХЛАЖДЕНИЕ ПЛОСКОЙ НАКЛОННОЙ ПОВЕРХНОСТИ ПЕННЫМ ПОТОКОМ}

\section{Резюме}

Представлены результаты экспериментального и аналитического исследования теплообмена между наклонной плоской поверхностью и потоком статически устойчивой ячеистой пены. Определено, что на поверхности образуется слой дренажной жидкости, толщина которого, температура и скорость течения влияют на интенсивность охлаждения. Эти параметры зависят от расхода температуры и газосодержания пенного потока. Аналитическим путем получены уравнения, пригодные для расчета гидродинамических параметров дренажного слоя. Экспериментально определено, что средний коэффициент теплоотдачи всей поверхности увеличивается до определенного максимального значения с увеличением скорости пенного потока. При дальнейшем увеличении скорости пенного потока происходит снижение коэффициента теплоотдачи. Представлено сравнение результатов, полученных экспериментальным путем, с аналитическим решением.

Ключевые слова: двухфазного потока пены, наклонной плоской поверхности, решение дренажный слой, теплообмен 